\title{
Neuroinvasive Action of SARS-CoV-2 in Coronavirus Disease (COVID-19): A Review
}

Geyse do Espírito Santos Rezende ${ }^{1}$, AlineFagundes Martins², Daniela RaguerValadão de Souza ${ }^{2}$, Makson Gleydson Brito de Oliveira ${ }^{3 *}$ and Lysandro Pinto Borges ${ }^{1}$

\author{
${ }^{1}$ Department of Pharmacy, Federal University of Sergipe, São Cristóvão, CEP 49100-000, Sergipe, Brazil \\ ${ }^{2}$ Department of Education and Health, Federal University of Sergipe, Lagarto, CEP 49400-000, Sergipe, Brazil \\ ${ }^{3}$ Department of Medicine, Federal University of Sergipe, Lagarto, CEP 49400-000, Sergipe, Brazil
}

${ }^{*}$ Corresponding author: Makson Gleydson Brito de Oliveira (PhD, Professor), Department of Medicine, Federal University of Sergipe, Av. Governador Marcelo Déda, 13, CEP 49400-000 Lagarto, Sergipe, Brazil; Tel: 55 (79) 36322080; E-mail: makson_gbo@hotmail.com

Received: September 15, 2020; Accepted: September 28, 2020; Published: October 8, 2020

\begin{abstract}
Background: SARS-CoV-2 can affect different organ systems, causing a range of symptoms that include fever, cough, myalgia, fatigue, headache, diarrhea and dyspnoea; in more severe cases acute respiratory distress, acute cardiac injury and secondary infection can develop and result in death. Skin lesions, ophthalmic changes and anosmia may also occur, which may be related to the effects of the virus on the central nervous system. Because it is an emerging virus, it is not yet known precisely how the virus can affect the human brain. The aim of the present study is therefore to investigate the causal relationship between SARS-CoV-2 infection and neurological manifestations, through scientific evidence.
\end{abstract}

Methods: A systematic search was carried out in the databases SciELO, Web of Science, Science Direct, PubMed, Embase and Scopus. Initially, 912 articles were identified; at the end of the selection process and after applying the inclusion and exclusion criteria, 18 articles were selected for this review.

Results: Of the selected articles, two did not associate the neurological symptoms with the new coronavirus; despite this, both did not exclude the possibility that COVID-19 actually has neuroinvasive potential. The remaining articles attributed the neurological changes evaluated to COVID-19.

Discussion: It was reported that COVID-19 manifests itself neurologically in different ways, including stroke, Guillan-Barré syndrome, encephalopathy, convulsion, dizziness and altered consciousness.

Conclusion: Neurological symptoms that compromise the central nervous system should not be ruled out in the diagnosis of the new coronavirus. It is important to investigate neurological changes, with or without the presence of respiratory changes, as these changes may appear as the initial symptoms of COVID-19.

Keywords: COVID-19, Neuroinvasive action, Neurological changes, SARS-CoV-2

\section{Introduction}

In recent decades, a number of coronaviruses with different characteristics have appeared. Due to their capacity for mutation, recombination and infection, there is a possibility that new coronavirus variations will continue to appear [1]. Recently, a new coronavirus called SARS-CoV-2, which causes the disease COVID-19, appeared. It started in Wuhan, China, in December 2019, but quickly reached the level of a pandemic disease [2,3]. The initial reports of the infection characterized the condition as pneumonia of unknown origin; however, it has been observed that COVID-19 can affect different organ systems, causing a range of symptoms that include fever, cough, myalgia, fatigue, headache, diarrhea and dyspnoea. In more severe cases, acute respiratory distress, acute cardiac injury and secondary infection can develop which may result in death [4]. Some studies describe other clinical pictures that seem to be associated with the new disease, with symptoms such as skin lesions, ophthalmic changes and anosmia - manifestations that may be associated with the Central Nervous System (CNS) [5-7]. Since SARS-CoV-2 is an emerging virus, it is not yet known to what extent the virus can affect the human brain; therefore, the present study aims to investigate the causal relationship between SARS-CoV-2 infection and neurological manifestations, through scientific evidence.

\section{Methods}

This article is a systematic review based on the following guiding question: "Is there a causal relationship between COVID-19 and neurological manifestations?"

\section{Search Strategy for the Identification of Studies}

A search of the literature was undertaken in six databases: ScIELO, Web of Science, Science Direct, PubMed, Embase and Scopus; the descriptors ("COVID-19" OR "CORONAVIRUS" OR "SarS-CoV-2" OR "Coronavirus infections") AND ("Neurological" OR "Nerve" OR "Brain" OR "Convulsion" OR "Nervous system") were used. Two reviewers independently participated in each review phase (screening, 
eligibility and inclusion) and a third independent reviewer was invited to resolve any conflicts in the selection process.

\section{Inclusion and Exclusion Criteria}

As an inclusion criterion, articles were selected that were available in full and free of charge in the databases, written in English, Portuguese or Spanish, and published in the period between 2019 and May 2020. The exclusion criterion were: systematic reviews, meta-analyses, letters to the editor, brief communications, perspective, editorials, studies addressing psychological problems, and articles that, after reading the title and abstract, could not identified as being relevant to the proposed theme. The first search of the databases identified 10,412 articles. After applying the inclusion criteria, 912 articles were selected, of which 317 were excluded because they were duplicate texts, leaving 595 articles to be analyzed from reading the title and abstract; after this reading, 556 articles that did not fit the study criteria were eliminated and the remaining 39 articles were selected for reading in full. After reading the full texts, 21 were excluded because they did not meet the criteria previously established, leaving 18 articles to be included in the review. Figure 1 shows the systematic search strategy used to select articles for this review.

\section{Results}

The data were organized according to the title, authorship, country, correlation between the new coronavirus and neurological changes and which neurological changes were mentioned in the articles. Table 1 shows the general characteristics of the articles identified by our systematic review.

\section{Cerebrovascular Accident (CVA)}

It is believed that COVID-19, in addition to invading the respiratory system, also causes negative effects on the nervous systems of people who are affected by this disease. Four of the studies identified in the review presented evidence of a relationship between COVID-19 infection and the development of cerebrovascular accident (CVA). A study carried out in Turkey discussed the clinical status of four patients aged between 45 and 77 years diagnosed with COVID-19 and who had acute ischemic CVA. Three of the four patients had high levels of D-dimer, and two of them had high levels of C-reactive protein (CRP); these increases may have played a considerable role in the formation of ischemia. From these findings, the authors suggested that there may be a relationship between COVID-19 and the development of ischemic cerebrovascular diseases, independently of the critical disease process [8].

Similar evidence was found in a study in the USA, in which four patients, still in the early stages of COVID-19 infection, were also diagnosed simultaneously with acute ischemic CVA. The four patients were over 70 years old and had altered mental status, weakness on either side of the body, as well as difficulty in finding words. The authors suggested that the CVA may have occurred due to hypercoagulability, which is a pathophysiology directly related to the COVID-19 infection [9]. Another study reported a case in which a 75-year-old patient, who was being treated for COVID-19, suddenly had neurological symptoms, with changes in muscle strength. Computed tomography findings of the head showed that the patient had suffered cerebral infarction and had high levels of D-dimer, suggesting hypercoagulability [10]. Corroborating the findings from the aforementioned studies, a larger study conducted with 214 patients in China reported that there were strong indications that SARS-CoV-2 can infect the nervous system and skeletal muscle, in addition to the respiratory system. Clinical data showed that just over 35\% of the study patients had neurological manifestations due to the infection. In people with severe infection, neurological involvement is greater, which includes ischemic or hemorrhagic CVA, acute cerebrovascular diseases, impaired consciousness and skeletal muscle damage [6].

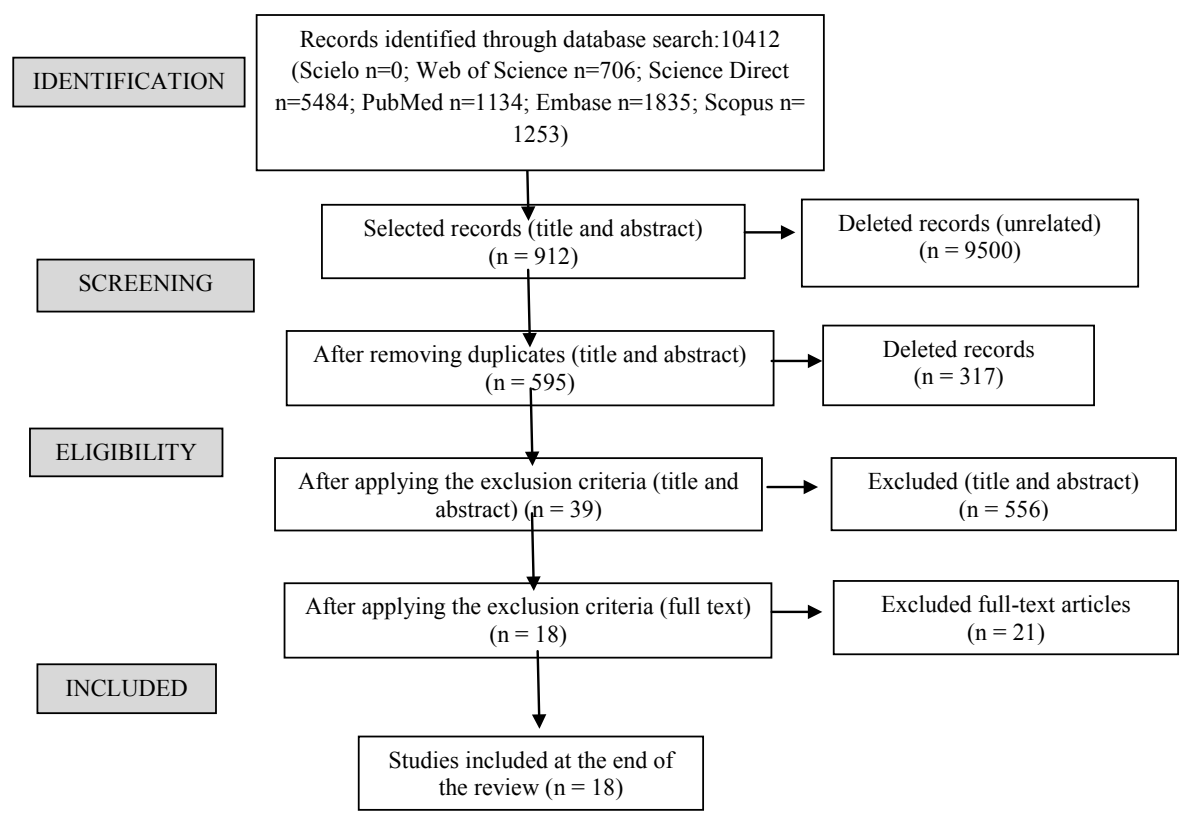

Figure 1: Flowchart of search and selection of articles. 
Table 1: Details of articles included in the review.

\begin{tabular}{|c|c|c|c|c|}
\hline Title & Author & $\begin{array}{c}\text { Year } \\
\text { (Country) }\end{array}$ & Correlation & Neurological manifestations \\
\hline SARS-CoV-2 can induce brain and spine demyelinating lesions & (Zanin et al., 2020) & $\begin{array}{l}2020 \\
\text { (Italy) }\end{array}$ & Yes & $\begin{array}{ll}- & \text { Anosmia } \\
- & \text { Ageusia } \\
\text { - } & \text { Convulsion } \\
\end{array}$ \\
\hline $\begin{array}{l}\text { Neurological Complications of Coronavirus Disease (COVID-19): } \\
\text { Encephalopathy, MRI Brain and Cerebrospinal Fluid Findings: Case } 2\end{array}$ & (Espinosa et al., 2020) & $\begin{array}{l}2020 \\
\text { (USA) }\end{array}$ & No & $\begin{array}{ll}\text { - } & \text { Encephalopathy } \\
\text { - } & \text { Altered mental state }\end{array}$ \\
\hline $\begin{array}{c}\text { Basal Ganglia Involvement and Altered Mental Status: A Unique Neurological } \\
\text { Manifestation of Coronavirus Disease } 2019 \\
\end{array}$ & $\begin{array}{l}\text { (Haddadi, Ghasemian } \\
\text { and Shafizad, 2020) }\end{array}$ & $\begin{array}{l}2020 \\
(\text { Iran }) \\
\end{array}$ & Yes & - $\quad$ Encephalopathy \\
\hline 2019 novel coronavirus pneumonia with onset of dizziness: a case report & (Kong et al., 2020) & $\begin{array}{l}2020 \\
\text { (China) }\end{array}$ & Yes & - $\quad$ Dizziness \\
\hline $\begin{array}{l}\text { Neurological Complications of Coronavirus Disease (COVID-19): } \\
\text { Encephalopathy }\end{array}$ & (Filatov et al., 2020) & $\begin{array}{l}2020 \\
\text { (USA) }\end{array}$ & No & $\begin{array}{ll}\text { - } & \text { Encephalopathy } \\
\text { - } & \text { Severe change in mental status }\end{array}$ \\
\hline COVID-19 and anosmia in Tehran, Iran & $\begin{array}{l}\text { (Gilani, Roditi and } \\
\text { Naraghi, 2020) }\end{array}$ & $\begin{array}{l}2020 \\
(\operatorname{Iran})\end{array}$ & Yes & $\begin{array}{ll}\cdot & \text { Hyposmia } \\
\cdot & \text { Anosmia } \\
\text { - } & \text { Ageusia } \\
\end{array}$ \\
\hline $\begin{array}{l}\text { Lessons of the month 1: A case of rhombencephalitis as a rare complication } \\
\text { of acute COVID-19 infection }\end{array}$ & (Wong et al., 2020) & $\begin{array}{l}2020 \\
\text { (England) }\end{array}$ & Yes & $\begin{array}{ll}\text { - } & \text { Encephalopathy } \\
\text { - } & \text { Rhomboencephalitis }\end{array}$ \\
\hline A first case of meningitis/encephalitis associated with SARS-Coronavirus-2 & (Moriguchiet al., 2020) & $\begin{array}{c}2020 \\
\text { (Yamanashi) }\end{array}$ & Yes & $\begin{array}{ll}\text { - } & \text { Encephalitis } \\
\text { - } & \text { Meningitis } \\
\text { - } & \text { Convulsion } \\
\text { - } & \text { Epileptic crisis }\end{array}$ \\
\hline COVID-19 Presenting with Seizures & $\begin{array}{l}\text { (Sohal and Mansur, } \\
\text { 2020) }\end{array}$ & $\begin{array}{c}2020 \\
\text { (USA) }\end{array}$ & Yes & $\begin{array}{ll} & \text { Convulsion } \\
\text { - } & \text { Altered mental state } \\
\end{array}$ \\
\hline $\begin{array}{l}\text { Early Guillain-Barré syndrome in coronavirus disease } 2019 \text { (COVID-19): a } \\
\text { case report from an Italian COVID-hospital }\end{array}$ & (Ottaviani et al., 2020) & $\begin{array}{l}2020 \\
\text { (Italy) }\end{array}$ & Yes & $\begin{array}{ll}\text { - } & \text { Guillain Barré Syndrome } \\
\text { - } & \text { Flaccid paralysis } \\
\text { - } & \text { Unilateral facial neuropathy } \\
\end{array}$ \\
\hline COVID-19 presenting as stroke & (Avula et al., 2020) & $\begin{array}{l}2020 \\
\text { (USA) }\end{array}$ & Yes & Stroke \\
\hline $\begin{array}{c}\text { Facial diplegia, a possible atypical variant of Guillain-Barré Syndrome as a } \\
\text { rare neurological complication of SARS-CoV-2 }\end{array}$ & $\begin{array}{l}\text { (Juliao Caamaño and } \\
\text { Alonso Beato, 2020) }\end{array}$ & $\begin{array}{l}2020 \\
\text { (Spain) }\end{array}$ & Yes & $\begin{array}{ll}\text { - } & \text { Guillain Barré Syndrome } \\
\text { - } & \text { Facial nerve palsy } \\
\end{array}$ \\
\hline Guillain-Barré syndrome related to COVID-19 infection & (Alberti et al., 2020) & $\begin{array}{l}2020 \\
\text { (Italy) }\end{array}$ & Yes & $\begin{array}{ll}\text { - } & \text { Guillain Barré Syndrome } \\
\text { - } & \text { Paresthesia } \\
\end{array}$ \\
\hline $\begin{array}{l}\text { Two patients with acute meningo-encephalitis concomitant to SARS-CoV-2 } \\
\text { infection }\end{array}$ & $\begin{array}{l}\text { (Bernard-Valnet et al., } \\
\text { 2020) }\end{array}$ & $\begin{array}{l}2020 \\
\text { (Switzerland) }\end{array}$ & Yes & $\begin{array}{ll}\text { - } & \text { Non-convulsive epileptic focal status } \\
\text { - } & \text { Viral meningoencephalitis } \\
\text { - } & \text { Tonic-clonic convulsion } \\
\text { Aseptic encephalitis }\end{array}$ \\
\hline $\begin{array}{l}\text { Plasmapheresis treatment in COVID-19-related autoimmune } \\
\text { meningoencephalitis: Case series }\end{array}$ & (Dogan et al., 2020) & $\begin{array}{l}2020 \\
\text { (Turkey) }\end{array}$ & Yes & - Autoimmune meningoencephalitis \\
\hline $\begin{array}{l}\text { A Case of Coronavirus Disease } 2019 \text { With Concomitant Acute Cerebral } \\
\text { Infarction and Deep Vein Thrombosis }\end{array}$ & (Zhou, B. et al., 2020) & $\begin{array}{l}2020 \\
\text { (China) }\end{array}$ & Yes & - Acute Cerebral Infarction \\
\hline Coexistence of COVID-19 and acute ischemic stroke report of four cases & (TUNÇ et al., 2020) & \begin{tabular}{|l}
2020 \\
(Turkey)
\end{tabular} & Yes & - $\quad$ Acute ischemic stroke \\
\hline $\begin{array}{l}\text { Neurologic Manifestations of Hospitalized Patients with Coronavirus Disease } \\
\qquad 2019 \text { in Wuhan, China }\end{array}$ & (Mao, Jin, et al., 2020) & $\begin{array}{l}2020 \\
\text { (China) }\end{array}$ & Yes & $\begin{array}{ll}\text { - } & \text { Ischemic stroke } \\
\text { - } & \text { Acute cerebrovascular disease } \\
\text { - } & \text { Convulsion } \\
\text { - } & \text { Change in sense of taste } \\
\text { - } & \text { Change insenseofsmell } \\
\text { - } & \text { Dizziness } \\
\text { - } & \text { Change in the level of consciousness } \\
\text { - } & \text { Muscle alteration }\end{array}$ \\
\hline
\end{tabular}

\section{Guillain-Barré Syndrome}

Studies show that the development of Guillan Barré Syndrome (GBS) is associated with COVID-19. A study [11] reported on a 71-year-old patient who had an acute and severe peripheral nervous system disorder, manifested by the subacute onset of paresthesia in the extremities of the limbs, followed by distal weakness that quickly evolved into severe flaccid tetraparesis. In general, these clinical findings were interpreted as a severe form of acute polyradiculoneuritis with prominent demyelinating characteristics, thus diagnosing GBS associated with COVID-19 [11]. Another case occurred in Spain, where a 61-year-old patient infected with COVID-19 was diagnosed with paralysis of the right peripheral facial nerve with an eye reflex that did not respond to the stimulus, but without other neurological symptoms. Due to facial diplegia, the authors believe that this neurological disorder is a rare variant of GBS directly related to COVID-19 infection [12]. Similarly, in Italy, a 66-year-old patient diagnosed with COVID-19 infection presented a clinical picture consistent with GBS, which started with progressive difficulty in walking and acute fatigue, initial distal weakness in the upper limbs, diffuse areflexia, but without any clear sensory deficits. The patient progressively developed proximal weakness in all limbs, dysesthesias and unilateral facial paralysis, with increasing flaccid weakness of the limbs [13]. 


\section{Encephalopathy}

There were two cases of encephalopathy and COVID-19 in the same center, in very close periods. In the first case, a 72 -yearold man hospitalized due to COVID-19 infection, did not show neurological improvement after sedation, did not respond to verbal commands, and did not show any reaction to noxious painful stimuli. For diagnostic clarification, an electroencephalogram (EEG) was performed after the patient had been sedated for 72 hours and showed only bilateral deceleration consistent with encephalopathy; however, when a puncture was performed with analysis of cerebrospinal fluid, no evidence was found to suggest meningitis or encephalitis. Thus, the authors concluded that the virus does not appear to cross the bloodbrain barrier, even if patients with COVID-19 develop encephalopathy. In this case, the authors believe that the cause of encephalopathy was multifactorial, but stressed that the virus may have contributed to the encephalopathy [14]. In the second case at the same center [15] reported on a 74-year-old patient who presented encephalopathy with severe mental status changes, without verbal communication and unable to follow any command, but without motor changes. The study reported that patients with COVID-19 may have encephalopathy; however, the authors did not attribute the neurological complications to COVID-19, and did not consider encephalopathy to be a symptom or complication of COVID-19 in this case.

In a similar study in Iran, the authors reported that a 54-yearold patient diagnosed with COVID-19 presented disorders related to encephalopathy, manifesting severe changes in mental status, without verbal communication and unable to follow any order; however, he did not present any motor alteration, being able to move all of his extremities. Therefore, the authors emphasized the importance of considering neurological manifestations as a consequence of COVID-19, and stressed that it is necessary to understand the pathways of viral neuroinvasion in order to improve the fight against the new coronavirus [16]. Unlike the previously mentioned cases, in a study from the United Kingdom the authors attributed neurological changes to COVID-19 infection, in a case report in which a 40 -yearold man developed acute brain stem dysfunction after being infected with COVID-19. Magnetic resonance imaging of the brain and cervical spine showed inflammation of the brain stem and upper cervical cord, leading to a diagnosis of inflammatory rhombencephalitis/myelitis, with the authors concluding that rhombencephalitis is a complication of COVID-19 infection [17].

A case of encephalitis as a result of COVID-19 was described by a study [18] in which a 24-year-old patient, hospitalized with a diagnosis of COVID-19, underwent an MRI scan that demonstrated abnormal findings in the temporal lobe, including in the hippocampus, suggesting encephalitis. The authors emphasized the importance of paying attention to the symptoms of encephalitis or cerebropathy, as these, in addition to respiratory symptoms, may be the first indication of SARS-CoV-2. A study [19] reported the case of two patients who developed autoimmune meningoencephalitis a few days after a diagnosis of mild COVID-19 infection. The patients developed severe neuropsychological symptoms suddenly and after specific exams, the hypothesis was that meningoencephalitis was derived from COVID-19; thus, the authors made the temporal association between acute SARS-CoV-2 infection and aseptic encephalitis with focal neurological symptoms and signs [19]. Finally, the study [20] reported on a series of cases in which the involvement of COVID-19 in the CNS was diagnosed in 6 of 29 intubated patients. A neurological investigation was carried out by means of specific tests, as some patients were unable to regain consciousness or developed agitated delirium during the weaning period, and found evidence that was compatible with autoimmune meningoencephalitis. The authors hypothesized that the neurological changes in the CNS were associated with COVID-19 [20].

\section{Convulsions}

In a case report, a 64-year-old patient with a positive result for COVID-19 infection presented with tonic-clonic seizure after being hospitalized with acute psychotic symptoms; he also had disorientation, strong attention deficit and psychotic symptoms. A routine electroencephalogram revealed non-convulsive epileptic focal status, which contributed to the association between acute COVID-19 infection and the neurological symptom [19]. In another study, a 54-year-old patient was admitted to hospital after being found unconscious at home; after a brief neurological examination the patient did not present any focal sensorimotor deficits. However, she presented disturbances of consciousness and convulsions, these symptoms being consistent with neurological involvement resulting from infection by SARS-CoV-2. The authors pointed out that sudden neurological impairment with convulsions in COVID-19 patients may occur due to CNS involvement and demyelinating lesions [21]. In agreement with the previous cases, another study reported a case of convulsion associated with COVID-19, in which a 24-yearold patient was transported to hospital following a convulsion and unconsciousness. In the ambulance, the patient had a transient generalized convulsion that lasted for about a minute. After arriving at hospital, the patient needed mechanical ventilation due to multiple epileptic convulsions. The differential diagnosis was post-convulsive encephalopathy [18].

A study in China reported the case of a patient who had a seizure characterized by the sudden onset of limb spasms, foaming at the mouth and loss of consciousness, which lasted for three minutes. The authors concluded that SARS-CoV-2 may infect the nervous system and cause several neurological changes [6]. Similarly, a case was presented in which a 72 -year-old patient, with no previous history of convulsion, developed several convulsive episodes after being transferred to the intensive treatment unit due to complications derived from COVID-19. The causal relationship between COVID-19 and neurological manifestations, such as the appearance of convulsion, was highlighted [22].

\section{Dizziness}

A study carried out in China highlighted the presence of dizziness as an initial symptom of COVID-19 infection. A 53-year-old patient complained of sudden dizziness for three days, with no apparent cause. He did not show any other neurological symptoms, and had a normal MRI result. However, he presented the characteristic symptoms of 
the infection and tested positive for COVID-19. From these findings, the authors concluded that COVID-19 can manifest itself in the nervous system, and suggest that greater attention should be paid to complaints of dizziness by patients, as it may be an early symptom of COVID-19 [23]. In a series of retrospective and observational cases that included 214 hospitalized patients with a confirmed diagnosis in the laboratory of infection with the new coronavirus, in patients who manifested changes in the central nervous system, dizziness was the most common symptom, being reported by 36 of the patients. The authors concluded that the more severe the patient's clinical condition, the worse the neurological manifestation associated with COVID-19 infection can be [6].

\section{Other Neurological Manifestations}

Studies cite other neurological changes, but not all discussed in detail how the changes occurred and how they were associated with COVID-19. Table 2 describes other manifestations mentioned in the studies selected by this review.

Most of the selected articles were case reports and some of them discussed more than one neurological disorder, not being restricted to just one symptom, as can be seen in Figure 2.

\section{Discussion}

COVID-19 is a relatively new disease, and it is not yet known how it behaves neurologically. Of the articles in this review, only two of the studies did not associate the neurological symptoms described with the new coronavirus, although neither excluded the possibility that COVID-19 has neuroinvasive potential. The number of studies that aim to explore the virus's action in the brain is growing, and there are several that have already shown neurological changes due to SARS-CoV-2 infection [24-28]. Current evidence, therefore, suggests that there is a risk of developing neurological diseases as a result of COVID-19, but it is not yet known what the possible long-term neurological sequelae might be [29]. In respect of this emerging evidence suggesting that SARS-CoV-2 is associated with neurological changes in patients with COVID-19, particularly in those with severe clinical manifestations, there are three feasible scenarios: the first is that the impact of SARSCoV-2 on the CNS could lead to neurological changes directly; the second is that it could aggravate pre-existing neurological conditions; and the third is that it could increase susceptibility to the infection, or aggravate the damage it causes [30,31]. It is believed that, together with the host's immunological mechanisms, SARS-CoV-2 can cause infections to result in neurological diseases [28].

A recent study highlighted the possibility that SARS-CoV-2 reaches the central nervous system through the olfactory bulb and infects the olfactory nerve; from there, it would spread to various parts of the brain via trans-synaptic transmission and infect the PreBotzinger complex (PBC) in the brain stem, the brain's respiratory center that controls the lungs, shutting off breathing and potentially causing death [30]. Olfactory and gustatory disorders have been found as prevalent symptoms among infected patients, and studies have stressed the importance of recognizing anosmia and ageusia as relevant symptoms in the diagnosis of COVID-19 [32,33]. Hyposmia and hypogeusia, together with dizziness, headaches and stroke have all been widely reported in patients with COVID-19, and could all be associated with neurological changes that affect the central nervous system [31]. Among the various neurological changes described in the articles in this review, the most prevalent was encephalopathy and similar changes, also with the presence of seizures, data that corroborates other studies which discuss the presence of encephalopathy associated with the new coronavirus $[34,35]$. The presence of necrotizing encephalitis associated with COVID-19 was also seen, but without evidence of viral isolation from cerebrospinal fluid. This neurological change can lead to brain dysfunction caused by the virus, which results in seizures

Table 2: Other manifestations described in the articles.

\begin{tabular}{|l|l|}
\hline Neurological Alteration & References \\
\hline Change in Taste/Ageusia & (GILANI, RODITI AND NARAGHI, 2020; MAO et al., 2020a) \\
\hline Smell Change/Anosmia/Hypogeusia & (GILANI, RODITI AND NARAGHI, 2020; MAO et al., 2020a; ZANIN et al., 2020) \\
\hline Change in mental status & (ESPINOSA et al., 2020; FILATOV et al., 2020; Mao et al., 2020a; SOHAL E MANSUR, 2020) \\
\hline Muscle alteration & (ALBERTI et al., 2020; MAO et al., 2020a) \\
\hline
\end{tabular}

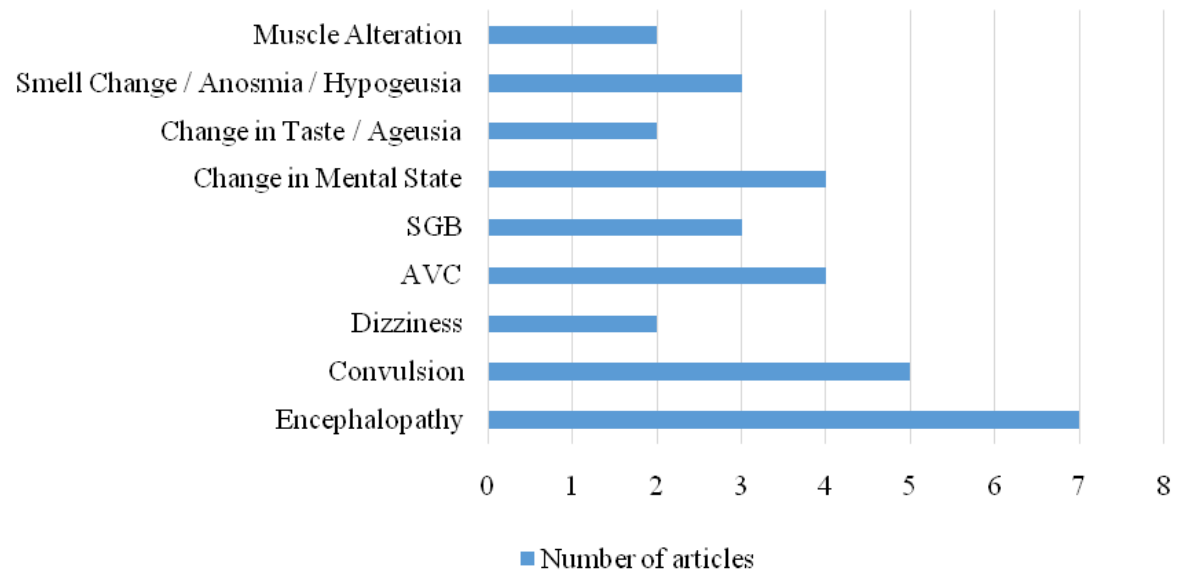

Figure 2: Symptoms cited in articles. 
and mental disorientation after infection [36]. The presence of seizures in the clinical picture calls attention to the possible involvement of SARS-CoV-2 in the neurological system. They can occur as a result of infection, an acute systemic disease, a primary neurological disease, or the adverse effect of medication on critically ill patients, and can present a variety of symptoms, ranging from seizure activity, subtle spasms and even lethargy [36,37]. In a number of studies identified in the review, Guillain-Barré syndrome was considered by the authors to be a possible important neurological complication of COVID-19 infection. It is imperative that medical teams pay attention to the presence of this syndrome, as it can lead to admission to the intensive care unit (ICU) and needs to be differentiated from a possible weakness acquired in the ICU after treatment [38-40].

Studies carried out recently have observed that patients with COVID-19 have an increased risk of cerebrovascular disease the incidence is similar to other critical illnesses. This has been widely reported as causing cytokine storm syndromes that may be one of the factors that leads to stroke [37,41]. Ischemic stroke associated with COVID-19 infection can occur in the context of a highly prothrombotic systemic state, and it is necessary to pay extra attention to the signs, as there is a strong association between SARS-CoV-2 and the development of systemic thromboembolisms due to a hypercoagulable state. This possibility, regardless of the patient's age, makes it necessary to increase the awareness of the health team about severe forms of ischemia and systemic stroke in patients with signs of COVID infection, in order to provide all patients with the best possible care [42-44]. In view of the severity of the neurological changes that can occur in infected patients, early assessments of neurological symptoms are necessary. The assessment should investigate headaches, disturbances in consciousness, paresthesia, ageusia, paralysis, among other factors. Timely cerebrospinal fluid analysis, and awareness and management of infection-related neurological complications are critical to improving the prognosis of critically ill patients [28].

\section{Conclusion}

The new coronavirus manifests itself neurologically in different ways, including headache, paraesthesia, encephalopathy, altered consciousness, Guillain-Barré syndrome, dizziness, seizure, stroke, among other conditions. These different neurological symptoms that affect patients and compromise the central nervous system should not be ruled out in the differential diagnosis of the new coronavirus. The health professional needs to be aware of these symptoms and request an evaluation from a neurologist to confirm the clinical suspicions; close attention should be paid to possible neurological conditions in patients who are suspected of having COVID-19 infection. The respiratory changes caused by COVID-19 infection are well documented, but it is important that attention is also focused on neurological changes, as they can cause serious damage to patients affected by the infection. This is particularly the case with patients who have comorbidities or are part of the risk group with previous diseases, as they are more susceptible to developing complications.

It is not yet known with certainty whether the neurological damage is temporary or permanent after the patient has recovered from COVID-19. Studies that aim to verify the presence of neurological damage in patients previously affected by the new coronavirus are necessary, so that the extent of any damage can be scientifically assessed. As the disease only emerged relatively recently, there is still a lack of knowledge in the scientific community regarding the subjects addressed here. Finally, the importance of investigating neurological changes is emphasized, with or without the presence of respiratory changes, as these changes may appear as the initial symptoms of COVID-19, thus being able to help in a faster and more accurate diagnosis, in order to provide better treatment for the patient.

\section{Acknowledgments}

The authors dedicate this article to all health professionals who are facing COVID-19. We are eternally grateful to them, and hope that our article can contribute to reducing the number of deaths.

Author contributions: All authors have read and agreed to the published version of the manuscript.

Funding: This research was not funded. The authors themselves financed it.

Conflicts of interest: The authors have declared that there is no conflict of interest.

\section{References}

1. Fehr AR, Perlman S (2015) Coronaviruses: An Overview of Their Replication and Pathogenesis. Coronaviruses: Methods and Protocols 1282: 1-282. [crossref]

2. Zhu N, Zhang D, Wang W, Li X, Yang B, et al. (2020) A Novel Coronavirus from Patients with Pneumonia in China, 2019. New England Journal of Medicine 382: 727733. [crossref]

3. World Health Organization (2020) Coronavirus disease (COVID-19) pandemic. Geneva: WHO. URL: htps://www.who.int/emergencies/diseases/novelcoronavirus-2019.

4. HUANG C, WANG Y, LI X, REN L, ZHAO J, et al. (2020) Clinical features of patients infected with 2019 novel coronavirus in Wuhan, China. The Lancet 395: 497-506. [crossref]

5. GALVÁN CC, CATALÀ A, CARRETERO HG, RODRÍGUEZ JP, FERNÁNDEZ ND, et al. (2020) Classification of the cutaneous manifestations of COVID-19: a rapid prospective nationwide consensus study in Spain with 375 cases. British Journal of Dermatology 183: 71-77. [crossref]

6. MAO L, JIN H, WANG M, HU Y, CHEN S, et al. (2020) Neurologic Manifestations of Hospitalized Patients With Coronavirus Disease 2019 in Wuhan, China. Jama Neurology 77: 683-690. [crossref]

7. ZHOU B, SHE J, WANG Y, MA X (2020) A Case of Coronavirus Disease 2019 with Concomitant Acute Cerebral Infarction and Deep Vein Thrombosis. Frontiers in Neurology 11: 2-5. [crossref]

8. TUNÇ A, ÜNLÜBAŞ Y, ALEMDAR M, AKYÜZ E (2020) Coexistence of COVID-19 and acute ischemic stroke report of four cases. Journal of Clinical Neuroscience 77: 227-229. [crossref]

9. AVULA A, NALLEBALlE K, NARULA N, SAPOZHNIKOV S, DANDU V, et al. (2020) COVID-19 presenting as stroke. Brain, Behavior, and Immunity 87: 115-119. [crossref]

10. ZHOU Y, LI W, WANG D, MAO L, JIN H, et al. (2020) Clinical time course of COVID-19, its neurological manifestation and some thoughts on its management. Stroke and Vascular Neurology 5: 177-179. [crossref]

11. ALBERTI P, BERETTA S, PIATTI M, KARANTZOULIS A, PIATTI ML, et al. (2020) Guillain-Barré syndrome related to COVID-19 infection. Neurology: Neuroimmunology and NeuroInflammation 7: 1-4. [crossref]

12. CAAMAÑO DSJ, BEATO RA (2020) Facial diplegia, a possible atypical variant of Guillain-Barré Syndrome as a rare neurological complication of SARS-CoV-2. Journal of Clinical Neuroscience 77: 230-232. [crossref] 
13. OTTAVIANI D, BOSO F, TRANQUILLINI E, GAPENI I, PEDROTTI G, et al (2020) Early Guillain-Barré syndrome in coronavirus disease 2019 (COVID-19): a case report from an Italian COVID-hospital. Neurological Sciences 41: 1351-1354.

14. ESPINOSA PS, RIZVI Z, SHARMA P, HINDI F, FILATOV A (2020) Neurological Complications of Coronavirus Disease (COVID-19): Encephalopathy, MRI Brain and Cerebrospinal Fluid Findings: Case 2. Cureus 12. [crossref]

15. FILATOV A, SHARMA P, HINDI F, ESPINOSA PS (2020) Neurological Complications of Coronavirus Disease (COVID-19): Encephalopathy. Cureus 12. [crossref]

16. HADDADI K, GHASEMIAN R, SHAFIZAD M (2020) Basal Ganglia Involvement and Altered Mental Status: A Unique Neurological Manifestation of Coronavirus Disease 2019. Cureus 12. [crossref]

17. WONG PF, CRAIK S, NEWMAN P, MAKAN A, SRINIVASAN K, et al. (2020) Lessons of the month 1: a case of rhombencephalitis as a rare complication of acute covid-19 infection. Clinical Medicine 20: 293-294. [crossref]

18. MORIGUCHI T, HARII N, GOTO J, HARADA D, SUGAWARA H, et al. (2020) A first case of meningitis/encephalitis associated with SARS-Coronavirus-2. International Journal of Infectious Diseases 94: 55-58. [crossref]

19. BERNARD-VALNET R, PIZZAROTTI B, ANICHINI A, DEMARS Y, RUSSO E, et al. (2020) Two patients with acute meningo-encephalitis concomitant to SARSCoV-2 infection. European Journal of Neurology, 2020. doi:10.1111/ene.14298

20. DOGAN L, KAYA D, SARIKAYA T, ZENGIN R, DINCER A, et al. (2020) Plasmapheresis treatment in COVID-19-related autoimmune meningoencephalitis: Case series. Brain, Behavior, and Immunity 155-158. [crossref]

21. ZANIN L, SARACENO G, PANCIANI PP, RENISI G, SIGNORINI L, et al. (2020) SARS-CoV-2 can induce brain and spine demyelinating lesions. Acta Neurochirurgica 162: 1491-1494. [crossref]

22. SOHAL S, MANSUR M (2020) COVID-19 Presenting with Seizures. ID Cases 20: e00782. [crossref]

23. KONG Z, WANG J, LI T, ZHANG Z, JIAN J (2020) 2019 Novel Coronavirus Pneumonia With Onset of Dizziness: a Case Report. Annals of Translational Medicine 8: 506-506. [crossref]

24. GILANI S, RODITI R, NARAGHI M (2020) COVID-19 and anosmia in Tehran, Iran. Medical Hypotheses 141: 109757. [crossref]

25. AZIM D, NASIM S, KUMAR S, HUSSAIN A, PATEL S (2020) Neurological Consequences of 2019-nCoV Infection : A Comprehensive Literature Review. Cureus

26. SANTOS MF, DEVALLE S, ARAN V, CAPRA D, ROQUE NR, et al. (2020) Neuromechanisms of SARS-CoV-2: A Review. Frontiers in Neuroanatomy 14: 1-12. [crossref]

27. MUNHOZ RP, PEDROSO JL, NASCIMENTO FA, ALMEIDA SM DE, BARSOTTINI OGP, et al. (2020) Neurological complications in patients with SARS-CoV-2 infection: a systematic review. Arquivos de neuro-psiquiatria 78: 290-300. [crossref]

28. WU Y, XU X, CHEN Z, DUAN J, HASHIMOTO K, et al. (2020) Nervous system involvement after infection with COVID-19 and other coronaviruses. Brain, Behavior and Immunity 87: 18-22. [crossref]
29. HENEKA MT, GOLENBOCK D, LATZ E, MORGAN D, BROWN R (2020) Immediate and long-term consequences of COVID-19 infections for the development of neurological disease. Alzheimer's research \& therapy 12: 69.

30. FELICE FG, TOVAR-MOLL F, MOLL J, MUNOZ DP, FERREIRA ST (2020) Severe Acute Respiratory Syndrome Coronavirus 2 (SARS-CoV-2) and the Central Nervous System. Trends in Neurosciences 43: 355-357. [crossref]

31. MAO L, WANG M, CHEN S, HE Q, CHANG J, et al. (2020) Neurological Manifestations of Hospitalized Patients with COVID-19 in Wuhan, China: a retrospective case series study. Med Rxiv 77:683-690. [crossref]

32. GIACOMELLI A, PEZZATI L, CONTI F, BERNACCHIA D, SIANO M, et al. (2020) Self-reported olfactory and taste disorders in SARS-CoV-2 patients: a cross-sectional study. Clinical infectious diseases: an official publication of the Infectious Diseases Society of America 2-3. [crossref]

33. LECHIEN JR, ESTOMBA CMC, SIATI DR, HOROI M, BON SDL, et al. (2020) Olfactory and gustatory dysfunctions as a clinical presentation of mild-to-moderate forms of the coronavirus disease (COVID-19): a multicenter European study. European Archives of Oto-Rhino-Laryngology 277: 2251-2261. [crossref]

34. ASADI-POOYA AA (2020) Seizures associated with coronavirus infections. Seizure: European Journal of Epilepsy 79: 49-52. [crossref]

35. YE M, REN Y, LV T (2020) Encephalitis as a clinical manifestation of COVID-19. Brain, Behavior, and Immunity 88: 945-946. [crossref]

36. POYIADJI N, SHAHIN G, NOUJAIM D, STONE M, PATEL S, et al. (2020) COVID-19-associated Acute Hemorrhagic Necrotizing Encephalopathy: imaging features. Radiology 296: 119-120. [crossref]

37. LI YC, BAI WZ, HASHIKAWA T (2020) Theneuroinvasive potential of SARS-CoV2 may play a role in the respiratory failure of COVID-19 patients. Journal of Medical Virology 92: 552-555. [crossref]

38. CAMDESSANCHE JP, MOREL J, POZZETTO B, PAUL S, THOLANCE Y, et al. (2020) COVID-19 may induce Guillain-Barré syndrome. Revue Neurologique 176: 516-518. [crossref]

39. SEDAGHAT Z, KARIMI N (2020) GuillainBarresyndrome associated with COVID-19 infection: A case report. Journal of Clinical Neuroscience 76: 233-235. [crossref]

40. ZHAO H, SHEN D, ZHOU H, LIU J, CHEN S (2020) Guillain-Barré syndrome associated with SARS-CoV-2 infection: causality or coincidence? The Lancet Neurology 19: 383-384. [crossref]

41. MEHTA P, MCAULEY DF, BROWN M, SANCHEZ E, TATTERSALL RS, et al. (2020) COVID-19: consider cytokine storm syndromes and immunosuppression. The Lancet 395: 1033-1034. [crossref]

42. BEYROUTI R, ADAMS ME, BENJAMIN L, COHEN H, FARMER SF, et al. (2020) Characteristics of ischaemic stroke associated with COVID-19. Journal of Neurology, Neurosurgery and Psychiatry 8-11. [crossref]

43. GONZÁLEZ-PINTO T, LUNA-RODRÍGUEZ A, MORENO-ESTÉBANEZ A, AGIRRE-BEITIA G, RODRÍGUEZ-ANTIGÜEDAD A, et al. (2020) Emergency Room Neurology in times of COVID-19: Malignant Ischemic Stroke and SARSCOV2. Infection. European Journal of Neurology 1: 1-2. [crossref]

44. SAIEGH FA, GHOSH R, LEIBOLD A, AVERY MB, SCHMIDT RF, et al. (2020) Status of SARS-CoV-2 in cerebrospinal fluid of patients with COVID-19 and stroke. Journal of Neurology, Neurosurgery \& Psychiatry 91: 846-848. [crossref]

\section{Citation:}

Geyse do Espírito Santos Rezende, AlineFagundes Martins, Daniela RaguerValadão de Souza, Makson Gleydson Brito de Oliveira, Lysandro Pinto Borges (2020) Neuroinvasive Action of SARS-CoV-2 in Coronavirus Disease (COVID-19): A Review. J Neurol Neurocrit Care Volume 3(2): 1-7. 